\title{
STRUCTURAL DEVELOPMENT OF THE DUTCH CENTRAL GRABEN
}

\section{B. M. Schroot}

Geological Survey of The Netherlands, P.O. Box 157, 2000 AD Haarlem, The Netherlands.

\section{Introduction}

After Heybroek (1975) described the structure of the Dutch Central North Sea Graben and NAM and RGD (1980) published a stratigraphic nomenclature of the Netherlands containing a stratigraphic model for the Jurassic sediments, further work continued, both within the industry and the Geological Survey. Because Herngreen and Wong (1989) set up a revised stratigraphy for the Late Jurassic of the Central Graben and neighbouring areas, it was felt necessary to have a closer look at the structural geology of the Central Graben and to review its hydrocarbon potential. The results of this study have been reported by Wong et al. (1989). This work just about coincided with an increased interest of the industry in

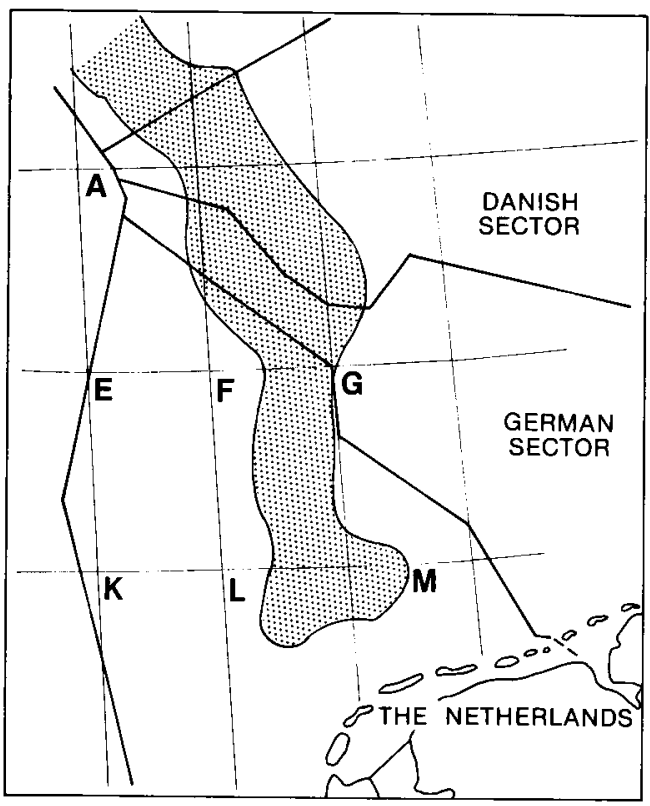

the south-eastern extension of the Graben because of the Dutch seventh round of exploration licenses.

In the publication by Wong et al. (1989) the chapter about the structural development of the Dutch Central Graben deals with the observations from seismic interpretation, a proposed subdivision of the area into four structural elements and a brief description of the structural history. Structural geology is illustrated by three regional profiles crossing the Central Graben.

The Central North Sea Graben in the Dutch sector of the North Sea is part of the large Mesozoic North Sea rift system, and can be regarded as the southernmost extension of the Central Graben s.l. which north of the Dutch sector is recognized in the German, Danish and Norwegian sectors (fig. 1). Within the area studied by Heybroek (1975), Clark-Lowes et al. (1987) and Wong et al. (1989) the rift system is very clearly expressed in the north (the Dutch B and F-quadrants), with the main structural trend being NNE-SSW and tapers out toward the south ( $\mathrm{L}$ and $\mathrm{M}$-quadrants) where a striking change in structural trend takes place. Compared to the simplified rift models described by McKenzie (1978) and Harding (1983), where listric normal faulting is the dominant deformation mechanism (Badley et al. 1984), the Dutch Central Graben shows a much more complicated picture.

Fig. 1 


\section{Observations on seismic profiles.}

The three regional profiles published by Wong et al. (1989) which cross the Dutch Central Graben have been constructed from a fair amount of seismic material. In the area it was observed that at least three superimposed effects complicate the simple rift model. First of all severe salt movements took place throughout the Mesozoic resulting in swells, domes and collapse structures. Particularly the major boundary fault systems are often overlain by elongated ridges of Zechstein salt. It should be noted however that the latest high quality seismic sections made it possible to interpret substantially smaller volumes of salt than were preferred in the past. Apart from Zechstein salt also Upper Triassic salt seems to have been subject to halokinesis in the deeper central parts of the Central Graben. Secondly considerable strike slip components of some of the movements led to more complicated appearances. Structures similar to flower structures as described by Harding (1985) have been observed and also changes in the sense of throw along some of the faults - otherwise difficult to explain - indicate that strike slip components played a role. Because the dip slip components still dominate it is best to speak of oblique slip faulting. Finally a major part of the basin underwent Late Cretaceous tectonic inversion.

Other important observations which illustrate the structural development of the basin are the asymmetric development from east to west and the change in the intensity and timing of the rifting from north to south. The Central Graben can in fact be regarded as a half graben. The western margin shows far larger dip slip offsets at the bounding faults, while at the eastern margin a more gradual change can be observed. The intensity of the rifting gradually decreases from the B-quadrant to the $\mathrm{L}$ - and M-quadrants, and the timing of events is later in the south. For instance the overstepping of the graben margins by Upper Jurassic sediments takes place later in the south. This is reflected by the age of these units.

\section{Structural elements.}

The area has been schematically subdivided into four main structural elements according to typical depth of the pre-rift basement, location of boundary faults, and typical post-Permian stratigraphic sequence. Because of the change in intensity of deformation this subdivision is most easily made in the north and gets more arbitrary toward the south. The elements are platform (characterized by base Zechstein at some $3000 \mathrm{~m}$, little or no Triassic sequence), intermediate platform (base Zechstein at 4000 to $5000 \mathrm{~m}$ and a thick Triassic sequence but little or no Jurassic), outer graben (with base Zechstein at least at $5000 \mathrm{~m}$ and a complete Triassic sequence overlain by thick Middle and Late Jurassic units) and inner graben (with base Zechstein deeper than $5000 \mathrm{~m}$, and very thick Jurassic sequence) respectively. The structural inversion coincides with the axis of the basin in the F-quadrant but turns to a NW-SE trend where the basin swings suddenly to a WNW-ESE trend at its southern margin. The elements are displayed in the general outline of the area in Wong et al. (1989) and Wong in this volume.

\section{Structural history}

The evolution of the basin is essentialy consistent with the two phase model of McKenzie (1978) with the rift phase starting in the Early Triassic and the sag phase starting during the Early Cretaceous, but superimposed are the complications mentioned above like the inversion during the Late Cretaceous, and the strike slip components of faulting also mentioned by Ziegler (1975) and Van Wijhe (1987). It looks like the oblique slip movements are most easily related to the Late Cretaceous inversion 
phase, thus giving transpressional deformation. Fig. 2 shows the major WNW-ESE trending faults in the south (both at the margins of the south-eastern subbasin in the $\mathrm{L}$ and $\mathrm{M}$ quadrants and on the platform around the E-quadrant). These faults are thought to have been reactivated several times during geologic history and to have displayed strike slip components particularly during the inversion phase. The junction area where this trend meets the main $\mathrm{N}-\mathrm{S}$ trending Central Graben remains an area that is intriguing and difficult to interpret.

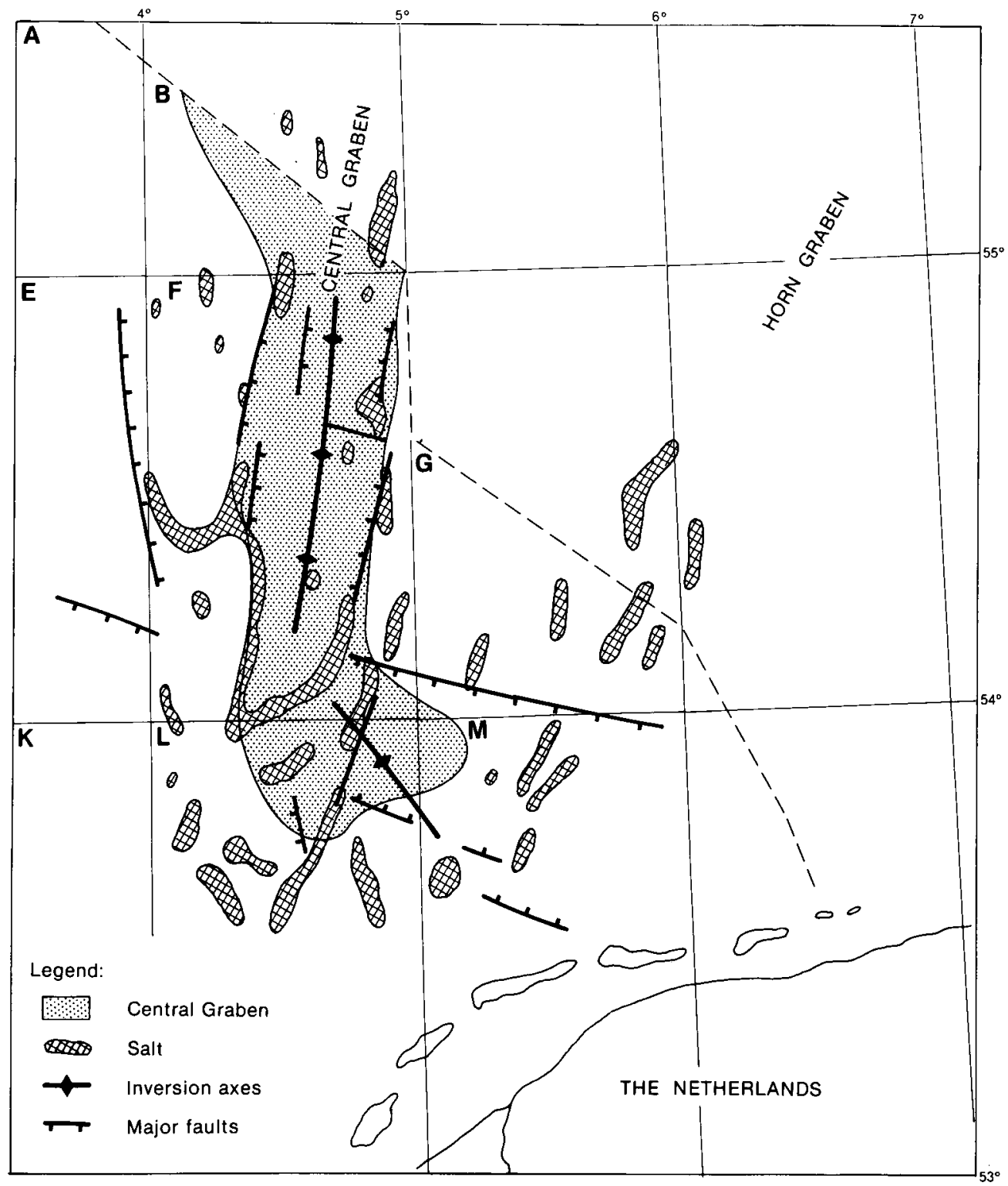

Fig. 2 


\section{References}

Badley, M. E., Egeberg, T. \& Nipen, O., (1984): Development of rift basins illustrated by the structural evolution of the Oseberg feature, Block 30/6, offshore Norway. J. Geol. Soc. London, $141,639-649$

Clark-Lowes, D. D., Kuzemko, N. C. J. \& Scott, D. A., (1987): Structure and petroleum prospectivity of the Dutch Central Graben and neighbouring platform areas. - In: Brooks, J. \& Glennie, K. W. (eds.): Proc. 3rd Conf. on Petroleum Geology of NW Europe, Graham \& Trotman, London, 337356.

Harding, T. P., (1983): Graben hydrocarbon plays and structural styles. Geol. Mijnbouw, 62, 3-23.

Harding, T. P., (1985): Seismic characteristics and indentification of negative flower structures, positive flower structures, and positive structural inversion. AAPG Bulletin, 69, 582-600.

Herngreen, G. F. W. \& Wong, Th. E., (1989): Revision of the "Late Jurassic" stratigraphy of the Dutch Central North Sea Graben. Geol. Mijnbouw, 67, 73-105.

Heybroek, P., (1975): On the structure of the Dutch part of the Central North Sea Graben. - In:
Woodland, A. W. (ed.) Petroleum and the Continental Shelf of NW Europe. 1 Geology, Applied Science Publishers, Barking, 339-352.

McKenzie, D. P., (1978): Some remarks on the development of sedimentary basins. Earth Planet. Sci. Lett., 40, 25-32.

Nederlandse Aardolie Maatschappij B. V. \& Rijks Geologische Dienst, (1980): Stratigraphic nomenclature of the Netherlands. - Kon. Ned. Geol. Mijnb. Gen., Verh. 32, pp. 77.

Van Wijhe, D. H., (1987): Structural evolution of inverted basins in the Dutch offshore. - In: Ziegler, P. A. (ed.): Compressional intra-plate deformations in the Alpine foreland. Tectonophysics, $137,171-219$.

Wong, Th. E., Van Doorn, Th. H. M. \& Schroot, B. M., (1989): "Late Jurassic" petroleum geology of the Dutch Central North Sea Graben. Geologische Rundschau, 78/1, 319-336.

Ziegler, W. H., (1975): Outline of the geological history of the North Sea. - In: Woodland, A. W. (ed.): Petroleum and the Continental Shelf of North-West Europe, 1, 165-190. 